\title{
Costus Root Extract Alleviates Blood Biochemical Derangements of Experimentally-Induced Hypo- and Hyperthyroidism in Mice
}

\author{
Yousry Bolkiny ${ }^{1}$, Ehab Tousson ${ }^{1^{*}}$, Afaf El-Atrsh $^{1}$, Mohamed Akela $^{1}$ \\ and Eman Farg ${ }^{1}$ \\ ${ }^{1}$ Department of Zoology, Faculty of Science, Tanta University, Tanta, Egypt.
}

Authors' contributions

This work was carried out in collaboration among all authors. Authors ET and YB designed the study, performed the statistical analysis and wrote the protocol. Author EF wrote the first draft of the manuscript and managed the analyses of the study. Authors AEA and MA managed the literature searches. All authors read and approved the final manuscript.

Article Information

DOI: $10.9734 / A R R B / 2019 / v 31 i 530063$

Editor(s):

(1) Dr. Manikant Tripathi, Department of Microbiology, Dr. Ram Manohar Lohia Avadh University, India.

(2) Dr. George Perry, Dean and Professor of Biology, University of Texas at San Antonio, USA.

Reviewers:

(1) Uchendu, Mbah Okuwa, Michael Okpara University of Agriculture, Nigeria.

(2) Muhammad Shahzad Aslam, Xiamen University, China Complete Peer review History: http://www.sdiarticle3.com/review-history/48325

Original Research Article

Received 19 February 2019

Accepted 30 April 2019

Published 10 May 2019

\begin{abstract}
Objectives: Thyroid hormones regulate all metabolic activities; therefore, it is not amazing that hepatic; renal dysfunctions and lipid alterations are commonly detected in patients with thyroid disorders. This study estimated some biochemical changes in post pubertal hyperthyroid and hypothyroid mice and their impacts on liver and kidney functions and also on changes in the lipid pattern. In addition, the ameliorating role of Costus root extract supplementation was examined. Material and Methods: A total of 60 male Swiss albino mice were randomly divided into 5 groups; control, control with costus extract, hypo- and hyper-thyroids post-treated with costus root extract. Results: Present results revealed that, a significant increase in serum thyrotropin (TSH), alanine transaminase $(A L T)$ and aspartate transaminase (AST), alkaline phosphatase (ALP), creatinine, urea, potassium, chloride, cholesterol and triglycerides levels in hypothyroid mice compared to control. On the other hand; a significant decrease in serumthyroxine $\left(T_{4}\right)$, tri-iodothyronine $\left(T_{3}\right)$,
\end{abstract}


albumin, total protein and calcium ions levels in hypothyroid mice compared to control. In contrast to hypothyroidism, a significant increase in serum $T_{3}, A L T, A S T, A L P$, creatinine, urea, sodium, potassium, chloride and total proteins levels in hyperthyroid mice compared to control. On the other hand; a significant decrease in serum TSH, $\mathrm{T}_{4}$, albumin, calcium ions cholesterol and triglycerides levels in hyperthyroid mice compared to control. Treatments of mice with Costus root extract in both hypo- and hyperthyroidism modulates the measured serum parameters.

Conclusions: Our results could propose that the extract of Costus roots can be used as an adjuvant co-therapy in hypo- and hyperthyroidism syndromes with propylthiouracil and Eltroxin replacement therapy, respectively

Keywords: Thyroid dysfunctions; Costus; hepatic and renal dysfunction; blood; mice.

\section{INTRODUCTION}

Thyroxine and tri-iodothyronine $\left(\mathrm{T}_{4} \& \mathrm{~T}_{3}\right)$ are thyroid hormones that essential for normal organ development and metabolic functions [1-4]. They regulate all metabolic activities such as growth rate, sodium/potassium pump, cholesterol secretion in the bile, heart rate, blood pressure, respiration, oxygen consumption, digestion strength, lipid, carbohydrate and protein metabolism, central nervous system function, and the actions of other endocrine glands and metabolic functions.

Hypothyroidism occurs when the thyroid gland does not produce enough thyroid hormones to meet the body's needs. Hypothyroidism is a progressive disorder presenting with different degrees of thyroid failure and metabolic consequences [5]. Low Levels of thyroid hormones can impose effects on behavior, growth, cardiac output, tissue oxygen consumption, muscle strength, and immune function [6]. On the other hand, Hyperthyroidism is characterized by increased secretion of thyroid hormones $T_{3}$ and/or $T_{4}$ [7-9]. Hyperthyroidism is commonly associated with increased food consumption, parallel with a loss of body weight and decreased serum cholesterol level $[4,10]$. Therefore, it is not amazing that disturbed metabolism in response to thyroid dysfunctions can cause changes in most of biochemical blood parameters.

Many plant extracts and their products have been shown to have significant antioxidant activity which may be an important property of medicinal plants associated with the treatment of several ill-fated diseases including liver toxicity [11-20].

Costus Saussurea lappais one plant of Asteraceae family, and it is described as an aromatic seasonal perennial plant. It's essential oil is used as medicinally tonic, stimulant and antiseptic, which differ from Costus spicatus, family Costaceae that belong to order Zingiberales. However, Costus or Saussurea lappa is one of these herbal plants that is rich in antioxidant, anti-hepatotoxic, anti-diabetic, antifungal, anthelmentic, anti-ulcer, anti-tumour, anti-inflammatory, antimicrobial effects and immuonostimulant activities. Fortunately, it is widely utilized in various indigenous system of medicine worldwide for treatment of a variety of disorders for instance diarrhea, tenesmus, dyspepsia, vomiting, and inflammation [21-23]. Therefore; the current study was designed to clarify the possible ameliorating effects of Costus root extracts in improving blood abnormalities against Propylthiouracil induced hypothyroidism and Eltroxin induced hyperthyroidism in male mice.

\section{MATERIALS AND METHODS}

\subsection{Chemicals}

Eltroxin (Thyroxin $100 \mathrm{mcg} ; 100$ Tablet) was obtained from Mercury Pharma Group Limited, Capital House, London EC4N 7BL, UK.

Costus: Saussurea lappa absolute, CAS Number: 8023-88-9, Robertet, Inc., France.

Other chemicals: reagents and buffers used in this study were purchased from local distributors and prepared in the research Lab. of Zoology Dept., Faculty of Science, Tanta Univ. Egypt.

\subsection{Animals}

A total of 60 male Swiss albino mice (Mus musculus), 6-8 weeks old, weighing $25 \pm 2 \mathrm{~g}$ from an inbred colony were used in the present study. Animals were provided with standard mice feed and water ad libitum. The mice were kept in 
the laboratory for 1 week before the experimental work and maintained on a standard rodent diet (20\% casein, $15 \%$ corn oil, $55 \%$ corn starch, $5 \%$ salt mixture and $5 \%$ vitaminzed starch; Egyptian Company of Oils and Soap, Kafr-Elzayat, Egypt) and water available ad libitum.

\subsection{Experimental Design and Treatments}

The sixty mice were equally divided into 6 groups.

G1: Control group in which mice did not receive any treatment.

G2: Costus group included rats received by oral gavages Costus extract $(50 \mathrm{mg} / \mathrm{Kg}$ body weight / 2day) for consecutive four weeks [14].

G3: Hypothyroid group; in which, mice received $0.05 \%$ 6-n-propyl-2-thiouracil (PTU) daily in drinking water for 4 weeks to induce the hypothyroid status [24].

G4: Hyperthyroid; mice received $100 \mu \mathrm{gg} / \mathrm{Kg}$ Eltroxin in drinking water for 4 weeks to induce the hyperthyroid status [10].

G5: Post treated hypothyroid; in which, mice received $0.05 \%$ 6-n-propyl-2-thiouracil (PTU) daily in drinking water for consecutive 4 weeks to induce the hypothyroid status and then mice received, by oral gavage, Costus extract (50 $\mathrm{mg} / \mathrm{Kg}$ body weight / 2day) for another 4 weeks (from 5th - 8th week).

G6: Post treated hyperthyroid; mice received 100 $\mu \mathrm{g} / \mathrm{Kg}$ Eltroxin in drinking water for consecutive 4 weeks to induce the hyperthyroid state and then mice received, by oral gavage, Costus extract (50 $\mathrm{mg} / \mathrm{Kg}$ body weight / 2day) for another 4 weeks (from 5th - 8th week).

At the end of the experiment, blood samples were collected from each mouse, through orbital veins, in non-heparinized glass tubes to obtain serum. Blood samples were centrifuged to obtain serum used for detection of thyroid hormones, liver and kidney functions and lipid profiles.

\subsection{Determination of Serum Thyroid Hormones}

Serum was used to determine the triiodothyronin $\left(T_{3}\right)$ according to Thakur et al.[25]; thyroxin $\left(T_{4}\right)$ according to Maes et al. [26] and thyrotropin
(TSH) according to Mandel et al. [27]. These hormones were determined by ELIZS method based on labeled antibodies using Horse radish peroxidase with its substrate according to the Manufacturer's instructions.

\subsection{Determination of Serum Liver Enzymes}

Serum was analyzed to determine alanine transaminase (ALT) and aspartate transaminase (AST) activities using commercial kit (Humann, Germany) according to the method of Schumann and Klauke [28]. Serum alkaline phosphatase (ALP) activity in serum was detected by using commercial kit (Humann, Germany) according to Moss and Henderson [29]. While, serum albumin level was estimated using commercial kit (Diamond, Egypt) according to Doumaset al. [30]. Measurement of the serum liver enzymes was performed spectrophotometrically based on the principles and procedures in kit's instructions provided by manufacturer.

\subsection{Determination of Kidney Functions and Electrolytes}

Photometric analysis of sera was carried out to determine urea and creatinine concentrations according to the method described by Kumar et al. [31]. Also, serum potassium, sodium, calcium and chloride ion levels were determined by using commercial kits (Sensa core electrolyte, India).

\subsection{Measurement of Lipid Profiles}

The serum concentration of cholesterol was estimated using a reagent kit (ReactivosSpinreact) according to the method described by Deeg and Ziegenohrm [32]. The serum level of triglycerides was also determined using a reagent kit (ReactivosSpinreact) according to the method described by Fossati and Prencipe [33].

\subsection{Statistical Analysis}

Data were expressed as mean values $\pm S R$ and statistical analysis was performed using one way ANOVA to assess significant differences among groups of all treatments.

The criterion for statistical significance was set at $p<.05$, at least, for the biochemical data. All statistical analyses were performed using SPSS 
statistical program, version 21 software package (SPSS $®$ Inc., USA).

\section{RESULTS}

\subsection{Toxicity}

In the present study, there were no deaths in neither hypo- nor hyperthyroid mice after costus treatments indicating no toxicity of costus at its dose regimen used. Mice received $0.05 \%$ 6-npropyl-2-thiouracil (PTU) in drinking water (group 3 , hypothyroid) had lower activity and loss of appetite as compared to other groups. In contrast, hyperthyroid mice had hyper activity and excessive appetite as compared to other groups.

On the other hand, hypothyroid mice, which treated with costus (group 2) or after approximate restoration of euthyroid status (groups 5\&6) showed higher activity than other non-treated groups. These results suggest that using of costus at $50 \mathrm{mg} / \mathrm{Kg}$ body weight of mice did not show any toxic sign and improved behavioral activities of mice toward euthyroid status.

\subsection{Induction of Hypothyroid Hyperthyroid Mice}

Table (1) showed that serum $\mathrm{T}_{3}$ and thyroitropin (TSH) levels were significantly decreased $(p<.05)$ and increased $(p<.05)$, respectively in hypothyroid mice (G3) as compared to control and costus groups (G1\&G2). Meanwhile, serum $\mathrm{T}_{3}$ and $\mathrm{TSH}$ levels showed significant increase and decrease, respectively in hyperthyroid mice (G4) as compared to control and costus groups (G1\&2). Serum $T_{4}$ in hypothyroid mice (G3) and hyperthyroid mice (G4) revealed a significance decrease $(p<.05)$, but $T_{4}$ level was higher in hypothyroid than hyperthyroid mice. On the other hand, treatment of mice with costus extract improved serum $\mathrm{T}_{4}$ to be around normal levels (Table 1). As shown in Table (1), the cotreatment of both hypo- and hyperthyroid mice with costus extract modulates disturbed thyroid hormones toward normal levels of the control.

\subsection{Changes in Serum Liver Functions}

As shown in Table (2), measurement of serum revealed significant increase $(p<.05)$ in ALT, AST and ALP activities in both hypo- and hyperthyroid mice, while the serum albumin level was significantly decreased $(p<.05)$ in both thyroid states compared to control and costus groups.

In contrast, estimation of the total protein content showed a significant decrease and increase in hypothyroid and hyperthyroid mice groups (G3\&G4), respectively compared to control and costus groups (G1\&G2). It was shown that treatment of hypothyroid and hyperthyroid mice with costus extract (G5\&G6) improved the liver function parameters to normal levels as in the control group (Table 2).

\subsection{Changes in Serum Kidney Functions}

In Table (3), serum levels of creatinine and urea in hypothyroid and hyperthyroid mice were significantly increased $(p<.05)$ as compared to control and costus groups. On the other hand, treatment of hypothyroid and hyperthyroid mice with costus extract (group 5\&6) decreased the kidney function indices to normal levels as in control group (Table 3).

\subsection{Changes in Serum Electrolytes}

Insignificance decreases in serum sodium $\left(\mathrm{Na}^{+}\right)$ and calcium $\left(\mathrm{Ca}^{++}\right)$ions were resulted in hypothyroid mice group while serum potassium $\left(\mathrm{K}^{+}\right)$and chloride $\left(\mathrm{Cl}^{-}\right)$ions were significantly increased $(p<.05)$ in hyperthyroid mice group as compared to control and costus groups (Table 4).

The $\mathrm{PH}$ value showed no changes in different groups under study. On the other hand, treatment of hypothyroid and hyperthyroid mice with costus extract (G5\&G6) changed the serum electrolytes to be around normal levels as in control group (Table 4).

\subsection{Changes in the Lipid Profiles}

Table 5 shows a significance increase $(p<.05)$ in serum cholesterol and triglyceride of hypothyroid mice and the two indices were significantly decreased in hyperthyroid mice group as compared to control and Costus groups. In contrast; treatment of hypothyroid and hyperthyroid mice with Costus extract (G5\&G6) normalized the cholesterol and triglyceride levels as in control group (Table 5).

\section{DISCUSSION}

Thyroid hormone helps the body to use energy, stay warm and keep the brain, heart, muscles, 
Table 1. Assessment of T3 (ng/dl), T4 (ng/dl) and TSH ( $\mu$ lU/ml) levels in different groups

\begin{tabular}{llll}
\hline Groups & T3 $(\mathbf{n g} / \mathbf{d l})$ & T4 $(\mathbf{n g} / \mathbf{d l})$ & TSH $(\boldsymbol{\mu l} \mathbf{l} / \mathbf{m l})$ \\
\hline G1 & $0.32^{\#} \pm 0.018$ & $4.83^{\#} \pm 0.152$ & $2.194^{\#} \pm 0.012$ \\
G2 & $0.36^{\#} \pm 0.013$ & $4.08^{\#} \pm 0.01$ & $2.29^{\#} \pm 0.065$ \\
G3 & $0.07^{*} \pm 0.010$ & $2.95^{*} \pm 0.326$ & $3.6^{*} \pm 0.129$ \\
G4 & $1.01^{\$} \pm 0.030$ & $2.15^{\$} \pm 0.082$ & $0.05^{\$} \pm 0.7$ \\
G5 & $0.22^{\# *} \pm 0.011$ & $4.82^{\#} \pm 0.089$ & $2.7^{\#} \pm 0.1$ \\
G6 & $0.71^{\# \Phi} \pm 0.065$ & $3.79^{\#} \pm 0.061$ & $1.94^{\#} \pm 0.15$ \\
\hline
\end{tabular}

Data are expressed as mean \pm SE of 10 observations. G1, Control; G2, Costus; G3, Hypothyroid; G4, Hyperthyroid; G5, Co-treated hypothyroid with costus group; G6, Co-treated hyperthyroid with costus. The symbols (\#, * \& \$) indicate a significant changes in comparison with G1 (negative control), G3 (hypothyroidism group) and G4 (hyperthyroidism group) respectively

Table 2. Changes in the liver functions [ALT, AST, albumin, ALP and total proteins] levels in different groups under study

\begin{tabular}{|c|c|c|c|c|c|}
\hline Groups & ALT (U/I) & AST (U/I) & Albumin (g/dl) & ALP (U/I) & T. protein (g/dl) \\
\hline G1 & $38.2^{\#} \pm 1.20$ & $149.4^{\#} \pm 3.56$ & $4.55^{\#} \pm 0.13$ & $160.2^{\#} \pm 4.26$ & $5.88^{\#} \pm 0.19$ \\
\hline G2 & $28.6^{\#} \pm 0.75$ & $137^{\#} \pm 2.83$ & $4.81^{\#} \pm 0.06$ & $153^{\#} \pm 4.30$ & $6.23^{\#} \pm 0.24$ \\
\hline G3 & $97.5^{*} \pm 3.91$ & $188.3^{*} \pm 9.05$ & $3.21^{*} \pm 0.06$ & $200.1^{*} \pm 7.32$ & $4.96^{*} \pm 0.14$ \\
\hline G4 & $55.8^{\$} \pm 2.52$ & $168.6^{\$} \pm 3.33$ & $2.43^{\$} \pm 0.05$ & $173^{\mathrm{s}} \pm 2.17$ & $7.25^{\$} \pm 0.28$ \\
\hline G5 & $29^{\#} \pm 1.14$ & $130.2^{\#} \pm 3.15$ & $3.62^{\#^{x}} \pm 0.04$ & $161.8^{\#} \pm 2.44$ & $6.80^{\# \bar{\phi}} \pm 0.10$ \\
\hline G6 & $25^{\#} \pm 1.67$ & $128^{\#} \pm 2.43$ & $3.43^{\#+} \pm 0.04$ & $122.2^{\# \bar{\phi}} \pm 7.25$ & $5.84^{\#} \pm 0.16$ \\
\hline
\end{tabular}

and other organs working as they should. Thyroid hormones regulate all metabolic activities such as growth rate, digestion strength, cholesterol secretion in the bile, respiration, oxygen consumption, heart rate, sodium/potassium pump, blood pressure, metabolism of lipid, carbohydrate and protein, regulate body temperature and the actions of other lymphoid organs, and other functions in the body [5-8,34,35]. It is well known that thyroid hormones contribute to the development and maintenance of homeostasis in multicellular organisms to control cell growth and differentiation [36].

The current study has been represented to examine the effect of a hyperthyroidism and hypothyroidism status on serum biochemical markers. In addition, the protective and ameliorative role of Costus root extract was studied in all treatments. Present results revealed elevation in serum $T_{3}, T_{4}$ and depression of TSH in mice receiving Eltroxin indicating the hyperthyroid state. This finding is compatible with other studies that used L-thyroxin as a thyroid drug agonist for induction of hyperthyroidism $[6,10]$. In the current study, a significant decrease $(p<.05)$ in $T_{3}$ and $T_{4}$ levels and significant increase $(p<.05)$ in TSH were detected in post treated hyperthyroid mice with costus root extract when compared with hyperthyroid mice. The current results coincide with studies of Shibutani et al. [37] and Beltagy et al. [10]. Also; the current results revealed depletion in serum $T_{3}, T_{4}$ and elevation in serum TSH in mice receiving0.05\% 6-n-propyl-2-thiouracil (PTU) in drinking water for consecutive 4 weeks indicating the hypothyroid state. This finding is compatible with other studies that used PTU as an antithyroid drug for induction of hypothyroidism [24,38,39].

Table 3. Changes in serum kidney functions in both hypo- and hyper-thyroid mice and after oral treatment with costus extract

\begin{tabular}{ccc}
\hline & Urea (mg/dl) & Creatinine (mg/dl) \\
\hline G1 & $26.2^{\#} \pm 0.8$ & $0.46^{\#} \pm 0.04^{a}$ \\
G2 & $24.2^{\#} \pm 1.02$ & $0.46^{\#} \pm 0.04$ \\
G3 & $39.2^{\star} \pm 0.78$ & $0.96^{*} \pm 0.03$ \\
G4 & $31.7^{\$} \pm 2.02$ & $0.62^{\$} \pm 0.04$ \\
G5 & $32.6^{*} \pm 1.21$ & $0.57^{\#} \pm 0.02$ \\
G6 & $28.2^{\$} \pm 2.15$ & $0.59^{\# \$} \pm 0.01$ \\
\hline \multicolumn{2}{c}{ Data are expressed as means \pm SD; $n=10 . G 1}$, \\
Control; G2, Costus; G3, Hypothyroid; G4, \\
Hyperthyroid; G5, Co-treated hypothyroid with costus \\
group; G6, Co-treated hyperthyroid with costus. The \\
symbols (\#, * \& \$) indicate a significant changes in \\
comparison with $\mathrm{G}_{1}$ (negative control), $\mathrm{G}_{3}$ \\
(hypothyroidism) and $\mathrm{G}_{4}$ (hyperthyroidism), \\
respectively
\end{tabular}


Table 4. Changes in serum electrolyte ions in both hypo- and hyper-thyroid mice and after oral treatment with costus extract

\begin{tabular}{|c|c|c|c|c|c|}
\hline & $\mathrm{Na}^{+} \mathrm{mEq} / \mathrm{L}$ & $\mathrm{K}^{+} \mathrm{mEq} / \mathrm{L}$ & $\mathrm{Ca}^{++} \mathrm{mEq} / \mathrm{L}$ & $\mathrm{Cl}^{-} \mathrm{mEq} / \mathrm{L}$ & $\mathrm{PH}$ \\
\hline G1 & $136.4^{\#} \pm 1.20$ & $5.72^{\#} \pm 0.12$ & $0.916^{\#} \pm 0.02$ & $107.4^{\#} \pm 0.80$ & $7.65^{\#} \pm 0.05$ \\
\hline $\mathrm{G} 2$ & $137^{\#} \pm 0.74$ & $5.72^{\#} \pm 0.06$ & $0.927^{\#} \pm 0.01$ & $104.3^{\#} \pm 1.18$ & $7.67^{\#} \pm 0.03$ \\
\hline G3 & $135.7^{\#} \pm 6.15$ & $7.12^{*} \pm 0.11$ & $0.789^{*} \pm 0.01$ & $117.3^{*} \pm 2.02$ & $7.77^{\#} \pm 0.09$ \\
\hline G4 & $142.4^{\$} \pm 3.06$ & $7.92^{\$} \pm 0.54$ & $0.87^{\$} \pm 0.04$ & $115.7^{\$} \pm 2.12$ & $7.55^{\Phi} \pm 0.03$ \\
\hline G5 & $137.7^{\#} \pm 0.63$ & $6.51^{\#^{x}} \pm 0.06$ & $0.992^{\#} \pm 0.01$ & $111^{\#^{*}} \pm 0.71$ & $7.70^{\#} \pm 0.02$ \\
\hline G6 & $142.2^{\# \bar{s}} \pm 1.12$ & $7.16^{\# \Phi} \pm 0.18$ & $1.113^{\#} \pm 0.04$ & $111.3^{\# \Phi} \pm 0.36$ & $7.44^{\$} \pm 0.02$ \\
\hline
\end{tabular}

Table 5. Changes in the lipid profile (cholesterol and triglycerides) levels in both hypo- and hyper-thyroid mice and after oral treatment with costus extract

\begin{tabular}{lll}
\hline Groups & Cholesterol mg/dl & Triglycerides $\mathbf{~ m g / d l}$ \\
\hline G1 & $147.2^{\#} \pm 2.653$ & $178.2^{\#} \pm 8.345$ \\
G2 & $145.2^{\#} \pm 7.235$ & $153.4^{\#} \pm 4.864$ \\
G3 & $163.2^{*} \pm 21.72$ & $244^{*} \pm 13.45$ \\
G4 & $82^{\$} \pm 4.827$ & $153^{\$} \pm 3.647$ \\
G5 & $111.2^{\#} 5.152$ & $121.2^{\#} \pm 6.576$ \\
G6 & $103.6^{\$} \pm 2.977$ & $118^{\$} \pm 3.209$ \\
\hline
\end{tabular}

Data are expressed as means \pm SR; $n=10 . G 1$, Control; G2, Costus; G3, Hypothyroid; G4, Hyperthyroid; G5, Cotreated hypothyroid with costus group; G6, Co-treated hyperthyroid with costus. The symbols (\#, *\& \$) indicate a significant changes in comparison with $G_{1}$ (negative control), $G_{3}$ (hypothyroidism) and $G_{4}$ (hyperthyroidism), respectively

PTU has been used as an anti-thyroid agent, that inhibits both the synthesis of thyroid hormones in the thyroid gland, and the conversion of thyroxine $\left(T_{4}\right)$ to its active form, triiodothyronine $\left(T_{3}\right)$ $[40,41]$.

In the present study; TSH was significantly increased in hypothyroid and significantly decreased in hyperthyroid rats; this result coincides with previous studies of Shibutani et al. [36]; Ibrahim et al. [34,42]; Tousson et al. [6,24,35]; Hafez and Tousson [7].

Liver plays an important role in thyroid hormones metabolism, and correspondingly, thyroid hormones regulate hepatic functions and bilirubin metabolism, therefore not surprisingly, syndromes of either organ have the potential to affect functions of the other [43]. Changes in the activities of plasma AST, ALT and ALP are the well-known secretory indicators of liver damage [43]. The current results revealed a significant increase $(p<.05)$ in serum ALT, AST, ALP and significant decrease in the albumen levels in hyperthyroid and hypothyroid mice confirmed that hyperthyroidism and hypothyroidism induced hepatic dysfunctions in mice. In the same concern, Giannini et al. [44]; Hull et al. [46] found a significant increase in serum ALT, AST and ALP in hyperthyroidism. The mechanism of the elevation in serum AST, ALT and ALP activities appears to be relative hypoxia in periventricular regions of the liver [46]. Also, Salama et al. [5] found a significant increase in serum ALT and AST and a decrease in total proteins and albumen in hypothyroidism.

In the current results, the treatment of hyperthyroid or hypothyroid mice with Costus root extract modulates liver function parameters as compared with non-treated hyperthyroidism or hypothyroidism. Eliza et al. [47] reported that Costus speciosus could alter plasma enzyme (AST, ALT, LDH, ALP and AP) levels to be around normal. Also, Nitin and Khosa [48] studied the hepatoprotective effect of the ethanolic extract of the rhizomes of Costus speciosus on carbon tetrachloride poisoned rats. Current results revealed a significance increase $(p<.05)$ in serum urea and creatinine in hypothyroid and hyperthyroid mice as compared to control and costus groups. The effect on thyroid hormones on electrolytes and minerals has not been well established and the underlying 
mechanisms are not well understood. The current serum sodium $\left(\mathrm{Na}^{+}\right)$and calcium $\left(\mathrm{Ca}^{++}\right)$ ions in hypothyroid mice group showed a significance decrease $(p<.05)$ while a significance increase $(p<.05)$ in serum potassium $\left(\mathrm{K}^{+}\right)$and chloride $\left(\mathrm{Cl}^{-}\right)$ions were detected in hyperthyroid mice group as compared to control and costus groups. Also, serum urea showed a significant increase in hyperthyroid mice groups as compared to control. These results are agreed with Malik and Hodgson [49] who studies the relationship between the thyroid gland and the liver. This finding was consistent with Iglesias et al. [50] who suggested that the increase in creatinine in hyperthyroid status is caused by reduced glomerular function and creatinine generation from possible myopathy and rhabdomyolysis (immediate release of creatinine through muscle break down). Hyperthyroidism enhances serum creatinine levels due to decreased clearance and increased production of creatinine.

Treatment of hyperthyroid mice with costus root extract decreases the elevation in serum creatinine in the hyperthyroid and hypothyroid mice. So the increase in serum creatinine is reversible in hyperthyroid or hypothyroid status after treatment with thyroid hormone supplementation. These results are in disagree with Bharti et al. [51] and Kumara et al. [52] who reported that no significant difference in the levels of the measured electrolytes among the controls and patients in subclinical hyperthyroidism.

So, thyroid patients should be regularly checked for serum electrolytes, where early detection and treatment can prevent further complications and will be helpful during the management of thyroid patients. Results of the current study are in agreement with Basu and Mohapatra [53] who studies the interactions between thyroid disorders and kidney disease.

The current serum levels of cholesterol and triglycerides were significantly increased in hypothyroid mice and significantly decreased in hyperthyroid mice group as compared to control and Costus groups. In contrast, oral treatment of hypothyroid and hyperthyroid mice with Costus extract recovered the cholesterol and triglyceride levels to normal levels as in control group.

Tousson et al. [54,55] and Ali et al. [56] who reported that the decrease of thyroid hormone (hypothyroidism) can cause an increase in levels of total cholesterol and low-density lipoprotein cholesterol and a possible change in high-density lipoprotein cholesterol due to a change in metabolic clearance. Herein, the administration of the aqueous extract of Costus decreased the levels of both total cholesterol and triglycerides. Such decrease in serum cholesterol level after administration of the aqueous extract of Indian Costus may be due to erase of LDL-cholesterol from plasma by increasing LDL-receptor activity.

\section{CONCLUSION}

The present study confirmed that hypo- or hyperthyroidism in male mice was associated with biochemical indices alterations, and also the treatment with Costus improved these alterations in blood indicating ameliorative therapeutic effect of costus during thyroid disorders.

So; our results could propose that the extract of Costus roots can be used as an adjuvant cotherapy in hypo- and hyperthyroidism syndromes with propylthiouracil and Eltroxin replacement therapy, respectively

\section{DATA AVAILABILITY}

The data used to support the findings of this study are available from the corresponding author upon request.

\section{ETHICAL APPROVAL}

The local committee approved the design of the experiments, and the protocol conforms to the guidelines of the Faculty of Science, Tanta University guide for animal, as approved by Institutional Animal Care and Use Committee (IACUC-SCI-TU-0041).

\section{COMPETING INTERESTS}

Authors have declared that no competing interests exist.

\section{REFFERENCES}

1. Hafez E, Masoud A, Barnous M, Tousson E. Apoptotic marker alternations in the spleen of experimentally hyperthyroid and hypothyroid rat. Journal of Bioscience and Applied Research. 2015;1(5):234-42.

2. Joeimon JL, Mohanraj K, Karthikeyan R, et al. Thyroid dysfunction in patients with liver cirrhosis. Journal of Dental and Medical Sciences. 2017;16(4):18-22. 
3. Kim D, Kim W, Joo SK, Bae JM, Kim JH, Ahmed A. Subclinical hypothyroidism and low-normal thyroid function are associated with nonalcoholic steatohepatitis and fibrosis. Clinical Gastroenterology and Hepatology. 2018;16(1):123-31.

4. Taha A, Hassan NS, Elbandrawy MM, Tousson EM. Different stages of hyperthyroidism: Alterations in proliferation, apoptosis, and histology of female rat ovary. Research Journal of Pharmaceutical, Biological and Chemical Science. 2018;9(3):1458-1472.

5. Salama AF, Tousson E, Ibrahim W, Hussein WM. Biochemical and histopathological studies of the PTUinduced hypothyroid rat kidney with reference to the ameliorating role of folic acid. Toxicology and industrial health. 2013;29(7):600-8.

6. Tousson E, Hafez E, Massoud AA, Sweef $\mathrm{O}$, Atta N. Protective role of folic acid in thyroxine-induced cardiac hypertrophy in hyperthyroid rat. Biomedicine \& Aging Pathology. 2013;3(2):89-95.

7. Hafez E, Tousson E. Thyroxine-induced cardiac hypertrophy: Role of ascorbic acid in treatment. Biomedicine \& Aging Pathology. 2014;4(2):161-7.

8. Mohamed TM, Tousson E, Beltagy DM, El Said AS. Biochemical studies in experimentally induced-hyperthyroid rats treated with folic and ascorbic acid. Biomedicine. 2014;2(4):60-5.

9. Salama AF, Tousson EM, Ibrahim WM, Elwan MS. Ameliorating role of folic acid in eltroxine induced hyperthyroid and oxidative stress in rat cortex, hypothalamus and hippocampus. Alexandria Journal of Veterinary Sciences. 2017; 55(1):210-6.

10. Beltagy DM, Mohamed TM, El Said AS, Tousson E. Beneficial role of ascorbic and folic acids antioxidants against thyroxininduced testicular dysfunction in hyperthyroid rats. Environmental Science and Pollution Research. 2016;23(17):17246-54.

11. Saggu S, Sakeran MI, Zidan N, Tousson E, Mohan A, Rehman H. Ameliorating effect of chicory (Cichorium intybus L.) fruit extract against 4-tert-octylphenol induced liver injury and oxidative stress in male rats. Food and chemical toxicology. 2014; 72:138-46.

12. Elmasry TA, Al-Shaalan NH, Tousson E, El-Morshedy K, Al-Ghadeer A. Star anise extracts modulation of reproductive parameters, fertility potential and DNA fragmentation induced by growth promoter Equigan in rat testes. Brazilian Journal of Pharmaceutical Sciences. 2018;54(1).

13. El-Masry TA, Al-Shaalan NH, Tousson E, El-Morshedy K, Al-Ghadeer A. P53 expression in response to equigan induced testicular injury and oxidative stress in male rat and the possible prophylactic effect of star anise extracts. Annual Research \& Review in Biology. 2017; 14(1):1-8.

14. Abd Eldaim MA, Tousson E, El Sayed IE, Awd WM. Ameliorative effects of Saussurea lappa root aqueous extract against Ethephon-induced reproductive toxicity in male rats. Environmental Toxicology. 2019;34(2):150-9.

15. Al-Rasheed NM, El-Masry TA, Tousson E, Hassan HM, Al-Ghadeer A. Hepatic protective effect of grape seed proanthocyanidin extract against Gleevecinduced apoptosis, liver Injury and Ki67 alterations in rats. Braz. J. Pharm. Sci. 2018;54(2):e17391.

16. Oyouni AA, Saggu S, Tousson E, Rehman H. Immunosuppressant drug tacrolimus induced mitochondrial nephrotoxicity, modified PCNA and Bcl-2 expression attenuated by Ocimum basilicum L. in CD1 mice. Toxicology reports. 2018;5:687-94.

17. Tousson E, Hafez E, Zaki S, Gad A. P53, Bcl-2 and CD68 expression in response to amethopterin-induced lung injury and ameliorating role of I-carnitine. Biomedicine \& Pharmacotherapy. 2014;68(5):631-9.

18. Tousson E, Hafez E, Zaki S, Gad A. The cardioprotective effects of L-carnitine on rat cardiac injury, apoptosis, and oxidative stress caused by amethopterin. Environmental Science and Pollution Research. 2016;23(20):20600-8.

19. Tousson E, Elgharabawy RM, Elmasry TA. Grape seed proanthocyanidin ameliorates cardiac toxicity induced by boldenone undecylenate through inhibition of NADPH oxidase and reduction in the expression of NOX2 and NOX4. Oxidative medicine and Cellular Longevity. 2018;ID 9434385. Available:https://doi.org/10.1155/2018/943 4385

20. Tousson E, Bayomy MF, Ahmed AA. Rosemary extract modulates fertility potential, DNA fragmentation, injury, KI67 and P53 alterations induced by etoposide in rat testes. Biomedicine \& Pharmacotherapy. 2018;98:769-74. 
21. de Kraker JW, Franssen MC, de Groot A, Shibata T, Bouwmeester HJ. Germacrenes from fresh costus roots. Phytochemistry. 2001;58:481- 487

22. Yaeesh $S$, Jamal $Q$, Shah A, Gilani A. Antihepatotoxic activity of Saussurealappa extract on D-galactosamine and lipopolysaccharide-induced hepatitis in mice. Phytotherapy Research. 2010;24(2): 233-234.

23. Tousson E, El-Atrsh A, Mansour M, Assem A. Histopathological and immunohisto chemical studies on the effects of Ethephon on liver and kidney in male rats. International Journal of Pathology and Biomarkers. 2019;1(1):1-6.

24. Tousson E, Ali EM, Ibrahim W, Mansour MA. Proliferating cell nuclear antigen as a molecular biomarker for spermatogenesis in PTU-induced hypothyroidism of rats. Reproductive Sciences. 2011;18(7):67986.

25. Thakur C, Saikia TC, Yadav RN. Total serum levels of triiodothyronine (T3) thyroxine (T4) and thyrotropine (TSH) in school going children of Dibrugarh district: an endemic goitre region of Assam. Indian J PhysiolPharmacol. 1997;41(2):167-70.

26. Maes $M$, Mommen $\mathrm{K}$, Hendrickx $\mathrm{D}$, Peeters D, D'Hondt P, Ranjan R, De Meyer F, Scharpe S. Components of biological variation, including seasonality, in blood concentrations of TSH, TT3, FT4, $\mathrm{PRL}$, cortisol and testosterone in healthy volunteers. Clinical endocrinology. 1997 May;46(5):587-98.

27. Mandel SJ, Brent GA, Larsen PR. Levothyroxine therapy in patients with thyroid disease. Annals of Internal Medicine. 1993 Sep 15;119(6):492-502.

28. Schumann G, Klauke R. New IFCC reference procedures for the determination of catalytic activity concentrations of five enzymes in serum: preliminary upper reference limits obtained in hospitalized subjects. Clinicachimicaacta. 2003 Jan 1;327(1-2):69-79.

29. Moss DW, Henderson AR. Clinical enzymology C.A. Burtis, E.R. Ashwood (Eds.).Tietz Textbook of Clinical Chemistry ( $\left.3^{\text {rd }} \mathrm{Ed}\right)$ 1999. W.B Saunders Company, Philadelphia, 1999;pp: 617- 721.

30. Doumas BT, Watson WA, Biggs HG. Albumin standards and the measurement of serum albumin with bromcresol green. Clinicachimicaacta. 1971 Jan 1;31(1):8796.
31. Kumar A, Sinha RA, Tiwari $M$, Singh $R$, Koji T, Manhas N, Rastogi L, Pal L, Shrivastava A, Sahu RP, Godbole MM. Hyperthyroidism induces apoptosis in rat liver through activation of death receptormediated pathways. Journal of hepatology. 2007 May 1;46(5):888-98.

32. Deeg R., J. Ziegenohrm, "Kinetic enzymatic method for automated determination of total cholesterol in serum," J. Clin.Chem., vol. 29, no. 10, pp. 1798-1802, 1983.

33. Fossati P, Prencipe L. Serum triglycerides determined colorimetrically with an enzyme that produces hydrogen peroxide. Clinical chemistry. 1982 Oct 1;28(10):2077-80.

34. Ibrahim W, Tousson E, El-Masry T, Arafa $\mathrm{N}$, Akela M. The effect of folic acid as an antioxidant on the hypothalamic monoamines in experimentally induced hypothyroid rat. Toxicology and industrial health. 2012 Apr;28(3):253-61

35. Mihara M, Erster S, Zaika A, Petrenko O, Chittenden T, Pancoska P, Moll UM. p53 has a direct apoptogenic role at the mitochondria. Molecular cell. 2003;11(3): 577-90.

36. Shibutani $M$, Woo $G H$, Fujimoto $H$, Saegusa Y, Takahashi M, Inoue K, Hirose M, Nishikawa A. Assessment of developmental effects of hypothyroidism in rats from in utero and lactation exposure to anti-thyroid agents. Reproductive Toxicology. 2009;28(3):297-307.

37. Tousson E, Ali EM, Ibrahim W, Mansour MA. Treatment with folic acid ameliorated the histopathological alterations caused by propylthiouracil-induced hypothyroid rat testes. Toxicology and industrial health. 2012;28(6):566-76.

38. Tousson E, Ali EM, Ibrahim W, Ashraf RM. Histopathological and immunohistochemical alterations in rat heart after thyroidectomy and the role of hemin and ketoconazole in treatment.Biomedicine\& Pharmacotherapy. 2012;66(8):627-32.

39. Gilbert ME, Paczkowski C. Propylthiouracil (PTU)-induced hypothyroidism in the developing rat impairs synaptic transmission and plasticity in the dentate gyrus of the adult hippocampus. Developmental Brain Research. 2003;145(1):19-29.

40. Ahmed OM, El-Tawab SA, Ahmed RG. Effects of experimentally induced maternal hypothyroidism and hyperthyroidism on the development of rat offspring: I. The development of the thyroid hormones- 
neurotransmitters and adenosinergic system interactions. International Journal of Developmental Neuroscience. 2010; 28(6):437-54.

41. Ibrahim W, Tousson E, Ali EM, Mansour MA. Folic acid alleviates oxidative stress and hyperhomocysteinemia involved in testicular dysfunction of hypothyroid rats. General and comparative endocrinology. 2011;174(2):143-9.

42. Khanam S. Impact of thyroid on liver metabolism. Endocrinol Res Metab. 2017; 1(2):6.

43. El-Khishin IA, Amer MG. Possible protective role of I-carnitine on diclofenac induced hepatotoxicity in adult male albino rats (Histological, Immunohistochemical and Biochemical Study). Egypt. J. Histol. 2010;33(2):341-52.

44. Giannini EG, Testa R, Savarino V. Liver enzyme alteration: A guide to clinicians. MAJ. 2005;172(3):367-79.

45. Hull K, Horenstein R, Naglieri R, Munir K, Ghany M, Celi FS. Two cases of thyroid storm associated cholestatic jaundice. Endocr Pract. 2007;13:476-480.

46. Biscoveanu, MD M, Hasinski, MD, Face, Facp S. Abnormal results of liver function tests in patients with graves' disease. Endocrine Practice. 2000;6(5):367-9.

47. Eliza J, Daisy $P$, Ignacimuthu $S$, Duraipandiyan V. Antidiabetic and antilipidemic effect of eremanthin from Costus speciosus (Koen.) Sm., in STZinduced diabetic rats. Chemico-biological interactions. 2009;182(1):67-72.

48. Verma N, Khosa RL. Evaluation of protective effects of ethanolic extract of Costus speciosus (Koenig) Sm. rhizomes on carbon tetrachloride induced hepatotoxicity in rats. J. of Natural Product Radiance. 2009;8(2):123-126.

49. Malik $\mathrm{R}$, Hodgson $\mathrm{H}$. The relationship between the thyroid gland and the liver. QJM. 2002:95:559-69.

50. Iglesias $\mathrm{P}$, Dı'ez J. Thyroid dysfunction and kidney disease. European J Endocrinology. 2009;160:503-515.

51. Bharti A, Shrestha S, Rai R, Singh MK. Assessment of serum minerals and electrolytes in thyroid patients. International Journal of Advances in Scientific Research. 2015;1(06):259-263.

52. Kumara $H$, Krishna $M$, Vishwanath $H$. The electrolytes imbalance between hypothyroidism and hyperthyroidism. International Journal of Current Research. 2016; 8:31031-31033.

53. Basu G, Mohapatra A. Interactions between thyroid disorders and kidney disease. Indian J Endocrinol Metab. 2012; 16:204-13.

54. Tousson E, Alghabban AJ, Harga HA. Thyroidectomy induced hepatic toxicity and possible amelioration by Ginkgo biloba leaf extract. Biomedicine \& Preventive Nutrition. 2014;4(3):391-7.

55. Tousson E, Ibrahim W, Arafa N, Akela MA. Monoamine concentrations changes in the PTU-induced hypothyroid rat brain and the ameliorating role of folic acid. Human \& experimental toxicology. 2012;31(3):2829.

56. Ali E, Ibrahim W, Ashraf RM, Tousson E. Interrelationship of hemeoxygenase and the oxidative stress in the cardiac tissues of thyroidectomized rats. Pharmacologia. 2013;4(12):623-33.

(c) 2019 Bolkiny et al.; This is an Open Access article distributed under the terms of the Creative Commons Attribution License (http://creativecommons.org/licenses/by/4.0), which permits unrestricted use, distribution, and reproduction in any medium, provided the original work is properly cited.

Peer-review history:

The peer review history for this paper can be accessed here: http://www.sdiarticle3.com/review-history/48325 